\title{
31-Tarih bölümü öğrencilerinin bakışıyla göç: Bir metafor analizi çalışması ${ }^{1}$
}

\section{Sezai ÖZTAŞ²} APA: Öztaş, S. (2020). Tarih bölümü öğrencilerinin bakışıyla göç: Bir metafor analizi çalışması.
RumeliDE Dil ve Edebiyat Araştırmaları Dergisi, (21), 523-535. DOI: 10.2900o/rumelide.835772.

\section{$\ddot{\mathbf{O} z}$}

Bu çalışmanın amacı, tarih bölümü öğrencilerinin göç kavramına ilişkin sahip oldukları metaforları tespit etmektir. Araştırmanın çalışma grubunu, 2019-2020 eğitim-öğretim yılı güz döneminde Kırklareli Üniversitesi Fen-Edebiyat Fakültesi Tarih Bölümü’nde öğrenime devam eden 4. Sinıf (Birinci Öğretim ve İkinci Öğretim) öğrencilerinden 85 öğrenci oluşturmaktadır. Araştırmanın verileri, öğrencilerinin "Göç ....... gibidir; çünkü ......." cümlesinin yazılı olduğu formları tamamlamasıyla elde edilmiştir. Öğrencilerin oluşturdukları metaforlar tespit edilerek bu metaforlar ortak özellikleri bakımından kategorize edilmeye çalışılmıştır. $\mathrm{Bu}$ çalışmada nitel araştırma yöntemlerinden olgubilim deseni kullanılmıştır. Elde edilen veriler, içerik analizi tekniğiyle analiz edilmiştir. Ayrıca IBM SPSS Statistics 20 programı ile nicel veri analizi de yapılmıştır. Toplanan verilere ait tanımlayıcı istatistikler ayrıntıları ile verilmiştir. Ayrıca "Cinsiyet", “Anne Ĕ̆itim Durumu”, "Baba Eğitim Durumu” ve “Memleket (Bölge Olarak)” ile örnek olarak verilen göç metaforu kategorileri arasında bir ilişki olup olmadığına bakılmıştır. Yapılan Ki-Kare Bağımsızlık Testi sonucunda bunların hiçbiri ile örnek olarak verilen göç metaforu kategorileri arasında bir ilişkiye rastlanmamıştır ( $\mathrm{p}>0,05)$.

Anahtar kelimeler: Öğretim, tarih, kavram, göç, metafor

\section{Migration with the view of the department of history students: A metaphor analysis study}

\begin{abstract}
The aim of this study is to determine the metaphors related to the concept of migration that the students of the history departments have. The study group of the research consists of 85 senior students (from both "day time education" and "evening education") who continue their education in the Department of History of Kirklareli University Faculty of Arts and Sciences in the fall semester of 2019-2020 academic year. In order to collect data, participants were asked to complete the forms which included the sentence "Migration are like. because.......". The metaphors proposed by the students were categorized in terms of their common characteristics. Phenomenological design, one of the qualitative research methods, was used in this study. The obtained data were analyzed with content analysis method. Additionally, a quantitative data analysis was performed via IBM SPSS Statistics 20 program as well. Descriptive statistics of the collected data were presented indetail. Moreover, it was analyzed whether there is an association between "the main categories of migration metaphors given as samples" and the following variables: "Gender", "Mother's Educational Status", "Father's Educational Status", "Hometown (as region)". As a result of the Chi-
\end{abstract}

Bu çalışma 23 Aralık 2019'da Tekirdağ’da düzenlenen "Rumeli Tekirdă̆ Göç” çalıştayında sözlü bildiri olarak sunulmuştur.

Doç. Dr., Tekirdă̆ Namık Kemal Üniversitesi, Fen Edebiyat Fakültesi, Tarih Bölümü (Tekirdağ, Türkiye), sezaioztaş@hotmail.com, ORCID ID: oooo-0002-1742-4200. [Araştırma makalesi, Makale kayıt tarihi: 26.10.2020kabul tarihi: 20.12.2020; DOI: 10.2900o/rumelide.835772]

Adres $\mid$ Address

İstanbul Medeniyet Üniversitesi, Eğitim Bilimleri Fakültesi, Türkçe ve Sosyal Bilimler Eğitimi Bölümü, Türkçe Eğitimi ABD Cevizli Turkish and Social Scinces Education, Turkish Language Teaching Kampüsü, Kartal-İstanbul/TÜRKIYE $\quad$ Education, Cevizli Campus, Kartal-İstanbul /TURKEY e-posta: editor@rumelide.com $\mid$ e-mail: editor@rumelide.com 
Square Independence Test, it turned out that there was no association between these variables and "the main categories of migration metaphors given as examples" ( $p>0.05)$.

Keywords: Teaching, history, concept, metaphor, migration

\section{Giriş}

Göç, insanlık tarihinin başlangıcından itibaren varolan bir nüfus hareketidir. İlkçağlarda yiyecek ihtiyacına binaen göç etmek zorunda kalan insanoğlu daha sonraki dönemlerde afetler, savaşlar vb. sebeplerle de göç etmek zorunda kalmıştır. Günümüzde insanoğlunun göçü devam etmekte ve gelecekte de devam edecektir.

Göç, bireylerin ya da grupların sembolik veya siyasal sınırların ötesine, yeni yerleşim alanlarına ve toplumlara doğru kalıcı hareketini içermektedir (Marshall, 1999: 685). Göç kavramına ilişkin literatürde farklı tanımların olduğu görülmektedir. Türk Dil Kurumu, Türkçe Sözlük'te göç, "ekonomik, toplumsal veya siyasî sebeplerle bireylerin veya topluluklarm bir ülkeden başka bir ülkeye, bir yerleşim yerinden başka bir yerleşim yerine gitme işi, muhaceret" (Türk Dil Kurumu, 1998: 556) olarak tanımlanmaktadır. Bir başka tanımda göç, "ekonomik, toplumsal, siyasal ya da savaş, kutlı doğal yıkım gibi nedenlerle, kişilerin veya toplulukların, çalışmak ve daha iyi yaşam koşulları bulmak umuduyla bir yerden başka bir yere giderek kesin ya da geçiciolarak yerleşmeleri (Türkiye Bilimler Akademisi, 2011: 502) olarak ifade edilmektedir. Uluslararası Göç Örgütü ise göçü, "bir kişinin veya bir grup insanı uluslararası bir sını geçerek veya bir Devlet içinde yer değisştirmesi. Süresi, yapısı ve nedeni ne olursa olsun insanların yer değiştirdiği nüfus hareketleri." olarak tanımlanmaktadır (Göç Terimleri Sözlüğü, 2013: 35-36).

Üniversite öğrenimine tarih bölümünde devam eden öğrencilerin göç kavramına ilişkin algılarının neler olduğunun belirlenmesi önemlidir. Bu alglları belirlemede önemli araçlardan biri de bireylerin geliştirmiş olduğu metaforlardır. Metafor kavramı "meta: öte" ve "pherein: taşımak, yüklenmek" kelimelerinden oluşmakta ve "bir yerden başka bir yere götürmek" anlamına gelmektedir (Lakoff ve Johnson, 2015: 15). Cerit (2008: 694) metaforların; insanların hayatı, çevreyi, olayları ve nesneleri nasıl gördükleri; farklı benzetmeler kullanarak açıklamaya çalışmada kullandıkları bir araç olarak düşünüldüğünü vurgulamıştır.

Göç kavramına ilişkin öğrencilerin metaforlarının neler olduğunu belirlemeye yönelik az sayıda araştırma bulunmakla birlikte (Canbaba, 2018; Gürkan, 2017; Kılınç, Karayel ve Koyuncu 2018; Tikman, Yıldırım ve Şentürk, 2017; Usta, 2016) Türkçe literatürde Fen-Edebiyat Fakültesi tarih bölümü öğrencilerinin göç kavramına ilişkin metaforlarının neler olduğu üzerine yapılan bir çalışmaya rastlanmamıştır. Bu bağlamda bu çalışma, tarih bölümü öğrencilerinin göç kavramına ilişkin bakış açısını ortaya koyabilmek adına önem kazanmaktadır.

$\mathrm{Bu}$ araştırmanın amacı, tarih bölümü öğrencilerinin göç kavramına ilişkin sahip oldukları algıları metaforlar aracılığıyla ortaya çıkarmaktır. Bu genel amaç çerçevesinde aşağıdaki sorulara cevap aranmışıır:

1. Öğrenciler, göç kavramına ilişkin sahip oldukları algıları hangi metaforlar aracılığıyla açıklamaktadır?

2. Bu metaforlar, ortak özellikleri bakımından, hangi kategoriler altında sınıflandırlmaktadır?

Adres

İstanbul Medeniyet Üniversitesi, Eğitim Bilimleri Fakültesi, Türkce ve Sosyal Bilimler Eğitimi Bölümü, Türkçe Eğitimi ABD Cevizli Kampüsü, Kartal-İstanbul/TÜRKIYE e-posta: editor@rumelide.com
Address

İstanbul Medeniyet University, Faculty of Education Sciences,

Turkish and Social Scinces Education, Turkish Language Teaching

Education, Cevizli Campus, Kartal-İstanbul /TURKEY

e-mail: editor@rumelide.com 
3. "Cinsiyet”, "Anne Eğitim Durumu”, "Baba Eğitim Durumu”, "Memleket (Bölge Olarak)” ile öğrencilerin örnek olarak verdikleri göç metaforu kategorileri arasında bir ilişki var mıdır?

\section{Method}

\subsection{Araştırma deseni}

$\mathrm{Bu}$ araştırmada nitel araştırma yöntemlerinden olgubilim deseni kullanılmıştır. Olgubilim (fenomenoloji) deseni, farkında olduğumuz ama derinlemesine ve ayrıntılı bir anlayışa sahip olmadığımız olgulara odaklanmaktadır. Olgular yaşadığımız dünyada olaylar, deneyimler, algılar, yönelimler, kavramlar ve durumlar gibi çeşitli biçimlerde karşımıza çıkabilmektedir. Olgubilim, tümüyle yabancı olmayan aynı zamanda da tam anlamını kavrayamadığımız olguları araştırmayı amaçlayan çalışmalar için uygun bir araştırma zemini oluşturur (Ylldırım ve Şimşek, 2008: 72). Elde edilen veriler, içerik analizi tekniğiyle analiz edilmiştir. Bu kapsamda öğrencilerin yanıtları üzerinden örnek olarak verdikleri göç metaforu kategorilerinin belirlenmesinden sonra bu kategorileri oluşturan katılımcı sayıları (frekans) ve oranları (yüzde) hesaplanmıştır. IBM SPSS Statistics 20 programı ile nicel veri analizi de yapılmıştır. Toplanan verilere ait tanımlayıcı istatistikler ayrıntıları ile verilmiştir. Ayrıca "Cinsiyet”, "Anne Eğitim Durumu", "Baba Eğitim Durumu”, "Memleket (Bölge Olarak)" ile örnek olarak verilen göç metaforu kategorileri arasında bir ilişki olup olmadığına bakılmıştır.

\section{2 Çalışma grubu}

Araştırmanın çalışma grubunu, 2019-2020 eğitim-öğretim yılı güz döneminde Kırklareli Üniversitesi Fen-Edebiyat Fakültesi Tarih Bölümü’nde öğrenime devam eden 4. Sınıf (Birinci Öğretim ve İkinci Öğretim) öğrencilerinden 85 öğrenci oluşturmaktadır. Araştırmaya katılan öğrencilerin cinsiyete göre frekans ve yüzde dağılımları Tablo 1'de gösterilmiştir.

\begin{tabular}{|l|l|l|}
\hline Cinsiyet & Frekans (n) & Oran (\%) \\
\hline Kız & 42 & 49,4 \\
\hline Erkek & 43 & 50,6 \\
\hline TOPLAM & 85 & 100,0 \\
\hline
\end{tabular}

Tablo 1. Öğrencilerin cinsiyetlerine göre frekans ve yüzde dağılımı

Araştırmaya katılanların 42'si kız ve 43'ü erkektir. Bu öğrencilerin \%49,4’ünü kızlar ve \%50,6'sını erkekler oluşturmaktadır (Tablo 1).

\subsection{Veri toplama aracı ve verilerin toplanması}

Araştırmaya katılan tarih bölümü öğrencilerinin "göç" kavramına ilişkin sahip oldukları metaforları ortaya çıkarmak amacıyla ilk önce metaforun ne olduğu örnekler ile açıklanmıştır. Daha sonra öğrencilerinin kişisel bilgilerinin bulunduğu ve "Göç ....... gibidir; çünkü .......” cümlesinin yazılı olduğu formları tamamlamalarıyla araştırmanın verileri elde edilmiştir.

\subsection{Verilerin analizi ve yorumlanması}

Bu çalışmada, elde edilen verilerin değerlendirilmesinde "içerik analizi” tekniği kullanılmıştır. İçerik analizinde temel amaç, toplanan verileri açlklayabilecek kavramlara ve ilişkilere ulaşmaktır. Betimsel analizde özetlenen ve yorumlanan veriler, içerik analizinde daha derin bir işleme tabi tutulur ve

\footnotetext{
\begin{tabular}{r|l} 
Adres & $\begin{array}{l}\text { Address } \\
\text { İstanbul Medeniyet Üniversitesi, Eğitim Bilimleri Fakültesi, Türkçe }\end{array}$ \\
İstanbul Medeniyet University, Faculty of Education Sciences,
\end{tabular} ve Sosyal Bilimler Eğitimi Bölümü, Türkçe Eğitimi ABD Cevizli $\quad$ Turkish and Social Scinces Education, Turkish Language Teaching Kampüsü, Kartal-İstanbul/TÜRKIYE Education, Cevizli Campus, Kartal-İstanbul /TURKEY e-posta: editor@rumelide.com $\mid$ e-mail: editor@rumelide.com
} 
betimsel yaklaşımla fark edilemeyen kavram ve temalar bu analiz sonucu keşfedilebilir. İçerik analizi yoluyla verileri tanımlamaya, verilerin içinde saklı olabilecek gerçekleri ortaya çıkarmaya çalışırız. İçerik analizinde temelde yapılan işlem, birbirine benzeyen verileri belirli kavramlar ve temalar çerçevesinde bir araya getirmek ve bunları okuyucunun anlayabileceği bir biçimde düzenleyerek yorumlamaktır (Yıldırım ve Şimşek, 2008: 227).

Öğrencilerin geliştirdikleri metaforların analiz edilmesi ve yorumlanmasında benzer çalışmalardaki (Aydın, 2010; Canbaba, 2018; Candan ve Öztaş, 2017; Gürkan, 2017; Kılınç, Karayel ve Koyuncu 2018; Saban, 2004; Saban, 2009; Tıkman, Ylldırım ve Şentürk 2017) yol izlenmiştir. Metaforların analiz edilmesi ve yorumlanması beş aşamada gerçekleştirilmiştir. Bu aşamalar şunlardır: (1) Adlandırma Aşaması, (2) Tasnif Etme (Eleme ve Arıtma) Aşaması, (3) Kategori Geliştirme Aşaması, (4) Geçerlik ve Güvenirliği Sağlama Aşaması ve (5) Verileri Bilgisayar Ortamına Aktarma Aşaması.

Adlandırma Aşaması: Metaforların uygun bir şekilde yazılıp yazılmadığına bakılmış, öğrencilerin yazmış oldukları metaforlar kodlanmıştır. Herhangi bir metaforun yazılmadığı kağıtlar işaretlenmiştir.

Tasnif Etme (Eleme ve Arıtma) Aşaması: Her bir metafor; konusu, kaynağı ve konu ile kaynak arasındaki ilişki bağlamında analize tabi tutulmuştur. Bütün öğrenciler geçerli metafor üretememişlerdir.

Kategori Geliştirme Aşaması: Bu aşamada, katılımcılar tarafından üretilen metaforlar, göç kavramına ilişkin sahip oldukları ortak özellikleri bakımından incelenmiştir ve kategorileştirilmiştir.

Geçerlik ve Güvenirliği Sağlama Aşaması: Araştırmanın geçerliğini sağlamak için veri analiz süreci detaylı bir biçimde açıklanmıştır. Araştırmanın güvenirliğini sağlamak amacıyla metaforlar ve oluşturulan kategoriler ile ilgili uzman 2 öğretim üyesi görüşüne başvurulmuştur. Farklı kategoride olduğu düşünülen metaforlar üzerinde tartışlarak kategorilere son şekli verilmiştir. Güvenirlik katsayısının hesaplanmasında Miles ve Huberman (1994)'ın formülü (Güvenirlik = görüş birliği / görüş birliği + görüş ayrılığı) kullanılmıştır. Bu hesaplama sonucunda ise \% 96 oranında bir uzlaşma sağlandığı görülmektedir.

Verileri bilgisayar ortamına aktarma aşaması: Verilerin nicel analizi için veriler bilgisayar ortamına aktarılmıştır. Verilerin nicel analizi; SPSS 20 Windows (Statistical Packages for Social Sciences) paket programında \%95 güven düzeyinde yapılmıştır. Bulgular kısmında sunulan nicel veri analizinin ayrıntıları şu şekildedir:

1) Frekans Analizi: “Cinsiyet”, “Öğretim Türü”, “Anne Eğitim Durumu”, “Baba Eğitim Durumu” ve "Memleket (Bölge Olarak)"e ait frekans ve oran bilgileri tablolar halinde verilmiştir.

2) Hipotez Testleri: Araştırmanın hipotezleri, “Ki-Kare Bağımsızlık Test”i ile incelenmiştir. Buna göre; ankete katılanların örnek olarak verdikleri göç metaforlarının (kategorik olarak) sırasıyla "Cinsiyet", "Anne Eğitim Durumu”, “Baba Eğitim Durumu” ve "Memleket (Bölge Olarak)” değişkenlerinin herbiri ile ilişkili olup olmadı̆̆ı araştırılmıştır.

\footnotetext{
Adres Address

İstanbul Medeniyet Üniversitesi, Eğitim Bilimleri Fakültesi, Türkçe İstanbul Medeniyet University, Faculty of Education Sciences, ve Sosyal Bilimler Eğitimi Bölümü, Türkçe Eğitimi ABD Cevizli Turkish and Social Scinces Education, Turkish Language Teaching Kampüsü, Kartal-İstanbul/TÜRKIYE Education, Cevizli Campus, Kartal-İstanbul /TURKEY e-posta: editor@rumelide.com $\mid$ e-mail: editor@rumelide.com
} 


\section{Bulgular}

Bu bölümde, veri analizlerinin sonuçları tablolarda verilmiştir.

1. Öğrenciler, göç kavramına ilișkin sahip oldukları algıları hangi metaforlar aracılı̆̆ıyla açılamaktadir?

\section{Öğrencilerin göç kavramına ilişkin sahip oldukları metaforlara ait genel bulgular}

Bu araştırmada elde edilen genel bulgulara göre, tarih bölümü öğrencileri göç kavramına ilişkin olarak 69 adet farklı metafor üretmişlerdir (Tablo 2). Öğrenciler tarafından göç kavramına ilişkin en çok tercih edilen metaforlar kuş $(f=8)$ ve bavul $(f=3)$ olmuştur. Bunların dışında aşk $(f=2)$, bir çiçek gibi toprağından kopmak $(f=2)$, deprem $(f=2)$, güneş $(f=2)$, karanlı $(f=2)$, leylek $(f=2)$, rüzgar $(f=2)$, yeni bir hayat $(f=2)$, yeniden doğmak $(f=2)$ metaforları birden fazla tercih edilen metaforlardır. Araştırmaya katılan tarih bölümü öğrencileri tarafından geliştirilen metaforlar alfabetik sıraya göre listelenmiş, her bir metafor ve her bir metaforu temsil eden öğrenci sayıları (frekansları) aşağıda verilmiştir (Tablo 2).

\begin{tabular}{|c|c|c|c|c|c|}
\hline No & Metaforlar & Frekans & No & Metaforlar & Frekans \\
\hline $\mathbf{1}$ & Afrika Hayvanları & 1 & 36 & Koyun Sürüsü & 1 \\
\hline 2 & Ağaç Budamak & 1 & $\mathbf{3 7}$ & Kedi Yavrusu & 1 \\
\hline 3 & Anne & 1 & 38 & Lambasız Sokakta Yürümek & 1 \\
\hline 4 & Astral Seyahat & 1 & 39 & Leylek & 2 \\
\hline 5 & Aşk & 2 & 40 & Mucize & 1 \\
\hline 6 & Ayna & 1 & 41 & Mum & 1 \\
\hline 7 & Ayrılmak & 1 & 42 & Ölüm & 1 \\
\hline 8 & Balık & 1 & 43 & Özgürlük & 1 \\
\hline 9 & Bavul & 3 & 44 & Parka Giden Çocuklar & 1 \\
\hline 10 & Bilgi & 1 & 45 & Rüzgar & 2 \\
\hline 11 & Bir Çiçek Gibi Toprağından Kopmak & 2 & 46 & Rüya & 1 \\
\hline 12 & Bir Direniş & 1 & 47 & Savaş Davulu & 1 \\
\hline 13 & Buğulu Camdan Bakmak & 1 & 48 & Sevdasını Geride Bırakan Aşık & 1 \\
\hline 14 & Bulut & 1 & 49 & Sevgiliden Ayrılmak & 1 \\
\hline 15 & Çile & 1 & 50 & Sığınak & 1 \\
\hline 16 & Çocuk & 1 & $\mathbf{5 1}$ & Suya Fırlatılmış Taş & 1 \\
\hline 17 & Deniz & 1 & 52 & Tren & 1 \\
\hline 18 & Denizdeki Dalga & 1 & 53 & Tünel & 1 \\
\hline 19 & Denizden Ayrllmak & 1 & 54 & Türkler & 1 \\
\hline 20 & Çöldeki Kum & 1 & 55 & Uçurtma & 1 \\
\hline 21 & Deprem & 2 & 56 & Üniversite Öğrencisi & 1 \\
\hline 22 & Depresyona Girmek & 1 & $\mathbf{5 7}$ & Yangin & 1 \\
\hline 23 & Evsiz Yurtsuz Kalmak & 1 & 58 & Yaprak & 1 \\
\hline & $\begin{array}{r}\text { nbul Medeniyet Üniversitesi, Eğitim Bilimleri Faki } \\
\text { ve Sosyal Bilimler Eğitimi Bölümü, Türkçe Ĕgitim } \\
\text { Kampüsü, Kartal-İstanb } \\
\text { e-posta: editor@r }\end{array}$ & \begin{tabular}{r|l} 
Adres & A \\
si, Türkcee & İs \\
3D Cevizli & T \\
TÜRKiYE & E \\
elide.com & e
\end{tabular} & \multicolumn{3}{|c|}{$\begin{array}{l}\text { Address } \\
\text { İstanbul Medeniyet University, Faculty of Education Sciences, } \\
\text { Turkish and Social Scinces Education, Turkish Language Teaching } \\
\text { Education, Cevizli Campus, Kartal-İstanbul /TURKEY } \\
\text { e-mail: editor@rumelide.com }\end{array}$} \\
\hline
\end{tabular}




\begin{tabular}{|c|c|c|c|c|c|}
\hline 24 & Fantastik Bir Macera & 1 & 59 & Yemyeşil Doğadan Çöle Geçmek & 1 \\
\hline 25 & Film Sahnesi & 1 & 60 & Yeni Bir Hayat & 2 \\
\hline 26 & Gizemli Bir Düşünce & 1 & 61 & Yeni Bir Hayata Başlamak & 1 \\
\hline 27 & Güneş & 2 & 62 & Yeni Bir Sayfa & 1 \\
\hline 28 & Hayat & 1 & 63 & Yeni Limanlara Yelken Açmak & 1 \\
\hline 29 & İlgi & 1 & 64 & Yeniden Dirilmek & 1 \\
\hline 30 & Kaplumbağa & 1 & 65 & Yeniden Doğmak & 2 \\
\hline 31 & Karanlık & 2 & 66 & Yeri Değiştirilmiş Çiçek & 1 \\
\hline 32 & Kiyafette Dikili Bir Yama & 1 & 67 & Yıkılan Taşlar & 1 \\
\hline 33 & Kendinden Vazgeçmek & 1 & 68 & Yol & 1 \\
\hline 34 & Kitap & 1 & 69 & Zulüm & 1 \\
\hline 35 & Kuş & 8 & & & \\
\hline
\end{tabular}

Tablo 2. Tarih bölümü öğrencilerinin "göç" kavramına ilişkin geliştirdikleri metaforlar ve onları temsil eden öğrenci sayısı (f)

\section{Bu metaforlar, ortak özellikleri bakımından, hangi kategoriler altında sinıflandırılmaktadır?}

\section{Tarih bölümü öğrencilerinin göç kavramına ilişkin sahip oldukları metaforların oluşturduğu kategoriler}

Bu metaforlar kategorize edilirken metaforun kelime anlamı değil, geliştirilen metafora ait gerekçe dikkate alınmış ve "çünkü" sonrası yapılan açıklamalardan hareket edilmiştir. Bu sebeple bazı metaforlar ("kuş" metaforu ve "bavul" metaforu) birden fazla kategoride kullanılmıştır. Verilen metaforların anlamları üzerinden iki farklı kategorizyona gidilmiş ve bu kategorizasyonlara ait dağılımlar aşağıdaki tablolarda verilmiştir. Tarih bölümü öğrencilerinin göç kavramına ilişkin metaforları incelendikten sonra ilk önce bunların negatif, nötr ve pozitif olma durumları tespit edilmiştir.

\begin{tabular}{lll}
\hline Metafor Kategorisi-1 & Frekans (n) & Oran (\%) \\
\hline Negatif & 39 & 45,9 \\
Nötr & 30 & 35,3 \\
Pozitif & 16 & 18,8 \\
\hline TOPLAM & 85 & 100,0 \\
\hline
\end{tabular}

Tablo 3. Tarih bölümü öğrencilerinin göç kavramına ilişkin sahip oldukları metaforların negatif, nötr ve pozitif olma durumları

Ankete katılanların \%45,9’u negatif, \%35,3’ü nötr ve \%18,8’i pozitif içerikli göç metaforu örneği vermiştir (Tablo 3). Katılımcıların yaklaşık yarısının göç kavramına ilişkin negatif algıya sahip oldukları görülmektedir.

Tarih bölümü öğrencilerinin göç kavramına ilişkin metaforlarının negatif, nötr ve pozitif olma durumları tespit edildikten sonra bu metaforlar 6 kategori üzerinden değerlendirilmiştir. Katılımcıların metaforlarından hareketle oluşturulan kategoriler şunlardır: "Doğal/sıradan eylem", "çaresizlik/bilinmezlik içinde yol alış", "iyi bir hayata kavuşma arzusu", "sürekli özlem duyma",

\footnotetext{
\begin{tabular}{r|l} 
Adres & Address \\
İstanbul Medeniyet Üniversitesi, Eğitim Bilimleri Fakültesi, Türkçe & İstanbul Medeniyet University, Faculty of Education Sciences,
\end{tabular} ve Sosyal Bilimler Eğitimi Bölümü, Türkce Eğitimi ABD Cevizli Turkish and Social Scinces Education, Turkish Language Teaching Kampüsü, Kartal-İstanbul/TÜRKIYE $\quad$ Education, Cevizli Campus, Kartal-İstanbul /TURKEY e-posta: editor@rumelide.com $\mid$ e-mail: editor@rumelide.com
} 
"zorunlu ayrılma/terk ediş", "yeni bir başlangıç". Tarih bölümü öğrencilerinin göç kavramına ilişkin sahip oldukları metafor kategorileri aşağıda gösterilmiştir (Tablo 4).

\begin{tabular}{|c|c|c|c|c|}
\hline Metafor Kategorisi-2 & Metafor & $\begin{array}{l}\text { Metafor } \\
\text { Sayisı }\end{array}$ & $\begin{array}{l}\text { Metafor } \\
\text { Frekansı } \\
\text { (Öğrenci } \\
\text { Sayısı) }\end{array}$ & $\begin{array}{l}\text { Metafor } \\
\text { Yüzdesi } \\
\text { (\%) }\end{array}$ \\
\hline Doğal/Sıradan Eylem & $\begin{array}{l}\text { Afrika Hayvanları, Bulut, Cocuk, Hayat, } \\
\text { Kitap, Kus (7), Leylek (2), Özgürlük, } \\
\text { Türkler, Yaprak }\end{array}$ & 10 & 17 & 20 \\
\hline $\begin{array}{l}\text { Çaresizlik/Bilinmezlik } \\
\text { İçinde Yol Alış }\end{array}$ & $\begin{array}{l}\text { Astral Seyahat, Bir Direniş, Buğulu } \\
\text { Camdan Bakmak, Çile, Çöldeki Kum, } \\
\text { Deniz, Denizdeki Dalga, Depresyona } \\
\text { Girmek, Evsiz Yurtsuz Kalmak, Fantastik } \\
\text { Bir Macera, Gizemli Bir Düsünce, Günes,, } \\
\text { Karanllk (2), Kedi Yavrusu, Koyun Sürüsü, } \\
\text { Lambasız Sokakta Yürümek, Ölüm, Rüya, } \\
\text { Rüzgar (2), Uçurtma, Yol }\end{array}$ & 21 & 23 & 27,1 \\
\hline $\begin{array}{l}\text { İyi Bir Hayata Kavuşma } \\
\text { Arzusu }\end{array}$ & $\begin{array}{l}\text { Anne, Assk, Ayna, Ayrilmak, Bilgi, Güneş, } \\
\text { İlgi, Kuş, Mucize, Mum, Sı̆̆ınak, } \\
\text { Üniversite Öğrencisi, Yeni Bir Hayata } \\
\text { Başlamak, Yeniden Dirilmek, Yeniden } \\
\text { Doğmak, Yeniden Doğuş }\end{array}$ & 16 & 16 & 18,8 \\
\hline Sürekli Özlem Duyma & $\begin{array}{l}\text { Aşk, Bir Çiçek Gibi Toprağından Kopmak, } \\
\text { Denizden Ayrilmak, Film Sahnesi, } \\
\text { Sevgiliden Ayrılmak, Yangın, Yemyeşil } \\
\text { Doğadan Çöle Geçmek, Zulüm }\end{array}$ & 8 & 8 & 9,4 \\
\hline $\begin{array}{l}\text { Zorunlu Ayrılma/Terk } \\
\text { Ediş }\end{array}$ & $\begin{array}{l}\text { Bavul, Deprem (2), Kendinden } \\
\text { Vazgeçmek, Parka Giden Çocuklar, Savaş } \\
\text { Davulu, Sevdasını Geride Bırakan Aşık, } \\
\text { Suya Furlatılmış Taş, Yeri Değiştirilmiş } \\
\text { Çiçek, Yıkılan Taşlar }\end{array}$ & 9 & 10 & 11,8 \\
\hline Yeni Bir Başlangıç & $\begin{array}{l}\text { Ağaç Budamak, Balık, Bavul (2), } \\
\text { Kaplumbağa, Kıyafette Dikili Bir Yama, } \\
\text { Tren, Tünel, Yeni Bir Hayat, Yeni Bir } \\
\text { Sayfa, Yeni Limanlara Yelken Açmak }\end{array}$ & 10 & 11 & 12,9 \\
\hline TOPLAM & & 74 & 85 & 100 \\
\hline
\end{tabular}

Tablo 4. Tarih Bölümü Öğrencilerinin Göç Kavramına İlişkin Sahip Oldukları Metafor Kategorileri

Ankete katılanların \%27,1'i "Çaresizlik/Bilinmezlik İçinde Yol Alış”, \%20’si "Doğal/Sıradan Eylem”, \%18,8'i, \%12,9'u "Yeni Bir Başlangıç", "İyi Bir Hayata Kavuşma Arzusu”, \%11,8’i "Zorunlu Ayrılma/Terk Ediş" ve \%9,4’ü "Sürekli Özlem Duyma" içerikli göç metaforu örneği vermiştir. Öğrencilerin göçü en çok "Çaresizlik/Bilinmezlik İçinde Yol Alış" (\%27,1) olarak gördükleri anlaşılmaktadır. (Tablo 4).

\section{Kategori 1: Doğal/sıradan eylem}

Bu kategorinin 10 metafor ve 17 öğrenciden (\%20) oluştuğu görülmektedir. Bu kategoride yer alan örnek bazı öğrenci ifadeleri aşağıda verilmiştir.

"Kuş gibidir. Çünkü kuşlarda göç ederler."

"Leylek gibidir. Çünkü leylekler de yer değisştirir."

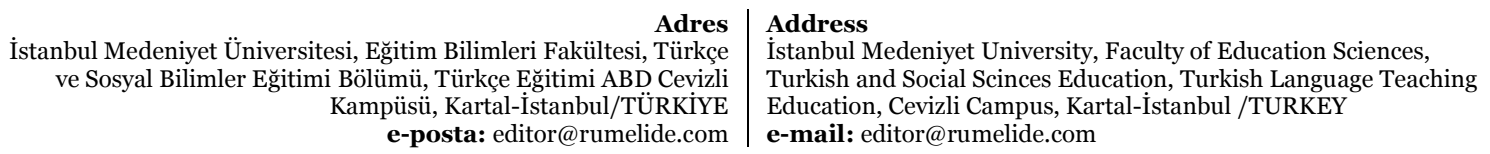


"Yaprak gibidir. Çünkü nasıl yaprak zamanı gelince dökülürse insanlarda zamanı gelince göç eder."

"Hayat gibidir. Çünkü hayat doğum ile ölüm arasında bize sunulan bir vakittir. Vakti dolan herkes de öbür dünyaya gider ve bu da bir göçtür."

\section{Kategori 2: Çaresizlik/bilinmezlik içinde yol alış}

Bu kategorinin 21 metafor ve 23 öğrenciden $(\% 27,1)$ oluştuğu görülmektedir. Bu kategori, öğrenciler tarafından en çok tercih edilen ve kategoriler içerisinde en çok öğrenci sayısı bulunan kategoridir. $\mathrm{Bu}$ kategoride yer alan örnek bazı öğrenci ifadeleri aşağıda verilmiştir.

"Fantastik bir macera gibidir. Çünkü sonunun ne olacağı ve neler yaşanacağı billinmez."

"Denizdeki dalga gibidir. Çünkü insanları nereye savuracă̆ı hiç belli değildir."

"Buğulu camdan bakmak gibidir. Çünkü net göremezsiniz."

"Depresyona girmek gibidir. Çünkü insan kendini belirsizlik içinde hisseder."

"Astral seyahat gibidir. Çünkü gittiğiniz yerde ne olacağımı bilemezsiniz."

\section{Kategori 3: İyi bir hayata kavuşma arzusu}

Bu kategorinin 16 metafor ve 16 öğrenciden $(\% 18,8)$ oluştuğu görülmektedir. Bu kategoride yer alan örnek bazı öğrenci ifadeleri aşağıda verilmiştir.

"Bilgi gibidir. Çünkü gittiğimiz yerler ufkumuzu genişletir, firsatlar sunar."

"Sığınak gibidir. Çünkü seni sahiplenir."

"Mucize gibidir. Çünkü tam pes ettiğin, tam bitti dediğin yerde tekrardan hayata başlayacağının göstergesi gibidir."

"Ayna gibidir. Çünkü ne tarafa tutarsak orasım görmemizi sağlar."

\section{Kategori 4: Sürekli özlem duyma}

Bu kategorinin 8 metafor ve 8 öğrenciden $(9,4)$ oluştuğu görülmektedir. Bu kategoride yer alan örnek bazı öğrenci ifadeleri aşağıda verilmiştir.

"Yangın gibidir. Çünkü özünü benimsediğin topraktan zorunlu veya isteyerek göç, içindeki memleket özleminin verdiği ateşi gün geçtikçe harlar."

"Film sahnesi gibidir. Çünkü ayrllklar kimi zaman özlem göz yaşları akıtır."

"Aşk gibidir. Çünkü gidersin ama akln hep bir yerde kalır."

"Sevgiliden ayrlmak gibidir. Çünkü sevgilisinden ayrllan ona nasıl özlem duyarsa göç eden de ayrrldığı yere özlem duyar."

\footnotetext{
\begin{tabular}{r|l} 
Adres & $\begin{array}{l}\text { Address } \\
\text { İstanbul Medeniyet Üniversitesi, Eğitim Bilimleri Fakültesi, Türkçe }\end{array}$ \\
İstanbul Medeniyet University, Faculty of Education Sciences,
\end{tabular} ve Sosyal Bilimler Eğitimi Bölümü, Türkçe Eğitimi ABD Cevizli Turkish and Social Scinces Education, Turkish Language Teaching Kampüsü, Kartal-İstanbul/TÜRKIYE $\quad$ Education, Cevizli Campus, Kartal-İstanbul /TURKEY e-posta: editor@rumelide.com $\mid$ e-mail: editor@rumelide.com
} 


\section{Kategori 5: Zorunlu ayrılma/terk ediş}

Bu kategorinin 9 metafor ve 10 öğrenciden $(\% 11,8)$ oluştuğu görülmektedir. Bu kategoride yer alan örnek bazı öğrenci ifadeleri aşağıda verilmiştir.

"Bavul gibidir. Çünkü sahibiyle birlikte zorunlu olarak yer değiştirir."

"Savaş davulu gibidir. Çünkü savaş davulları çaldığı zaman iradeleri dışında insanların olduğu yerden geri dönmemek üzere gitmelerini sağlar."

"Deprem gibidir. Çünkü insanları evlerinden kopartr."

"Parka giden çocuklar gibidir. Çünkü çocukları parka götüren ebeveynler belli bir süre sonra onlar oradan alp götürürler. Çocuklar istemese de gitmek zorunda kahrlar."

\section{Kategori 6: Yeni bir başlangıç}

Bu kategorinin 10 metafor ve 11 öğrenciden $(\% 12,9)$ oluştuğu görülmektedir. Bu kategoride yer alan örnek bazı öğrenci ifadeleri aşağıda verilmiştir.

"Tünel gibidir. Çünkü bize yol açar ve hayatta yeni bir sayfa açmamıza vesiledir."

"Balık gibidir. Çünkü kendine uygun koşullarda yaşam alanı belirler."

"Yeni limanlara yelken açmak gibidir. Çünkü her şeyinizi brrakıp yeni bir hayata adım atmaya karar vermişsinizdir."

"Yeni bir hayat gibidir. Çünkü göç ettiğimiz yere gelirken arkamızda o güne kadar orada yaşadiğımız hayatı burakıp yeni bir hayata başlarız."

\section{Frekans analizi}

\begin{tabular}{|l|c|c|}
\hline Öğretim Türü & Frekans (n) & Oran (\%) \\
\hline Birinci Öğretim & 43 & 50,6 \\
\hline İkinci Öğretim & 42 & 49,4 \\
\hline TOPLAM & 85 & 100,0 \\
\hline
\end{tabular}

Tablo 5: Öğrencilerin öğretim türüne göre dağılımı

Ankete katılanların \%50,6'sı birinci öğretim ve \%49,4'ü ise ikinci öğretim öğrencisidir (Tablo 5).

\begin{tabular}{|l|l|l|l|l|}
\hline \multirow{2}{*}{ Ĕ̆gitim Durumu } & \multicolumn{2}{l|}{ Anne } & \multicolumn{2}{l|}{ Baba } \\
\cline { 2 - 5 } & Frekans (n) & Oran (\%) & Frekans (n) & Oran (\%) \\
\hline Okur-Yazar Değil & 7 & 8,2 & 0 & 0 \\
\hline Okur-Yazar (Okul Bitirmemiş) & 11 & 12,9 & 7 & 8,2 \\
\hline
\end{tabular}




\begin{tabular}{|l|l|l|l|l|}
\hline İlkokul Mezunu & 35 & 41,2 & 36 & 42,4 \\
\hline Ortaokul Mezunu & 18 & 21,2 & 21 & 24,7 \\
\hline Lise Mezunu & 9 & 10,6 & 15 & 17,6 \\
\hline Ön Lisans Mezunu & 3 & 3,5 & 1 & 1,2 \\
\hline Lisans Mezunu & 0 & 0 & 0 & 0 \\
\hline TOPLAM & 85 & 100,0 & 85 & 100,0 \\
\hline
\end{tabular}

Tablo 6: Anne ve babaların eğitim durumlarının dağılımları

Ankete katılanların anne ve babalarına ait eğitim durumlarının dağılımı yukarıdaki tabloda verilmiştir (Tablo 6).

\begin{tabular}{|l|l|l|}
\hline Memleket (Bölge Olarak) & Frekans (n) & Oran (\%) \\
\hline Marmara Bölgesi & 25 & 29,4 \\
\hline Ege Bölgesi & 2 & 2,4 \\
\hline Karadeniz Bölgesi & 22 & 25,9 \\
\hline İç Anadolu Bölgesi & 16 & 18,8 \\
\hline Akdeniz Bölgesi & 1 & 1,2 \\
\hline Doğu Anadolu Bölgesi & 13 & 15,3 \\
\hline Güneydoğu Anadolu Bölgesi & 6 & 7,1 \\
\hline TOPLAM & 85 & 100,0 \\
\hline
\end{tabular}

Tablo 7: Memleketlerin (bölge olarak) dağılımı

Ankete katılanların \%29,4’ü Marmara Bölgesi, \%2,4’ü Ege Bölgesi, \%25,9’u Karadeniz Bölgesi, \%18,8’i İç Anadolu Bölgesi, \%1,2’si Akdeniz Bölgesi, \%15,3’i Doğu Anadolu Bölgesi ve \%7,1’i Güneydoğu Anadolu Bölgesi kökenlidir (Tablo 7).

3. "Cinsiyet", "Anne Eğitim Durumu”, "Baba Eğitim Durumu” ve "Memleket (Bölge Olarak) ile öğrencilerin örnek olarak verdikleri göç metaforu kategorileri arasında bir ilişki var mıdır?

\section{Hipotez testleri}

\begin{tabular}{|c|c|c|c|c|c|c|c|}
\hline & & \multirow[b]{2}{*}{$\mathrm{n}$} & \multicolumn{3}{|c|}{ GÖÇ METAFORU KATEGORİSİ } & \multirow[b]{2}{*}{$\chi^{2}$} & \multirow[b]{2}{*}{$p$} \\
\hline & & & Negatif & Nötr & Pozitif & & \\
\hline \multirow{3}{*}{ CİNSİYET } & $\mathrm{Kuz}$ & 42 & 17 & 17 & 8 & \multirow{3}{*}{1,163} & \multirow{3}{*}{0,559} \\
\hline & Erkek & 43 & 22 & 13 & 8 & & \\
\hline & Toplam & 85 & 39 & 30 & 16 & & \\
\hline
\end{tabular}

Tablo 8: Ki-kare ilişki testi (cinsiyet-göç metaforu kategorisi) sonuç tablosu 
Ki-Kare bağımsızlık testi sonucuna göre öğrencilerin cinsiyeti ile örnek olarak verdikleri göç metaforu kategorileri arasında istatistiksel olarak anlamlı bir ilişkiye rastlanmamıştır $\left(\chi^{2}{ }_{(2)}=1,163, p>0,05\right)$ (Tablo 8).

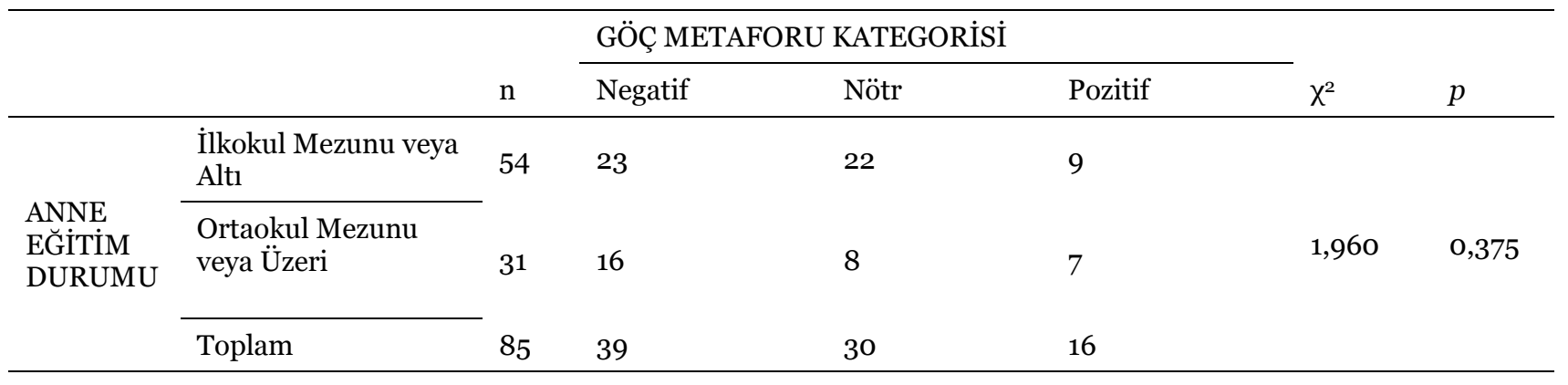

Tablo 9: Ki-Kare ilişki testi (anne eğitim durumu-göç metaforu kategorisi) sonuç tablosu

Ki-Kare bağımsızlık testi sonucuna göre öğrencilerin "Anne Eğitim Durumu" ile örnek olarak verdikleri göç metaforu kategorileri arasında istatistiksel olarak anlamlı bir ilişkiye rastlanmamıştır $\left(\chi^{2}(2)=1,1960, p>0,05\right)$ (Tablo 9).

\begin{tabular}{|c|c|c|c|c|c|c|c|}
\hline \multicolumn{8}{|c|}{ GÖÇ METAFORU KATEGORİSI } \\
\hline & & $\mathrm{n}$ & Negatif & Nötr & Pozitif & $\chi^{2}$ & $p$ \\
\hline \multirow{3}{*}{$\begin{array}{l}\text { BABA } \\
\text { EĞİTIM } \\
\text { DURUMU }\end{array}$} & $\begin{array}{l}\text { İlkokul Mezunu veya } \\
\text { altı }\end{array}$ & 44 & 19 & 17 & 8 & \multirow{3}{*}{0,454} & \multirow{3}{*}{0,797} \\
\hline & $\begin{array}{l}\text { Ortaokul Mezunu } \\
\text { veya üzeri }\end{array}$ & 41 & 20 & 13 & 8 & & \\
\hline & Toplam & 85 & 39 & 30 & 16 & & \\
\hline
\end{tabular}

Tablo 1o: Ki-Kare ilişki testi (baba eğitim durumu-göç metaforu kategorisi) sonuç tablosu

Ki-Kare bağımsızlık testi sonucuna göre öğrencilerin baba eğitim durumu ile örnek olarak verdikleri göç metaforu kategorileri arasında istatistiksel olarak anlamlı bir ilişkiye rastlanmamıştır $\left(\chi^{2}{ }_{(2)}=0,454\right.$, $p>0$,05) (Tablo 10).

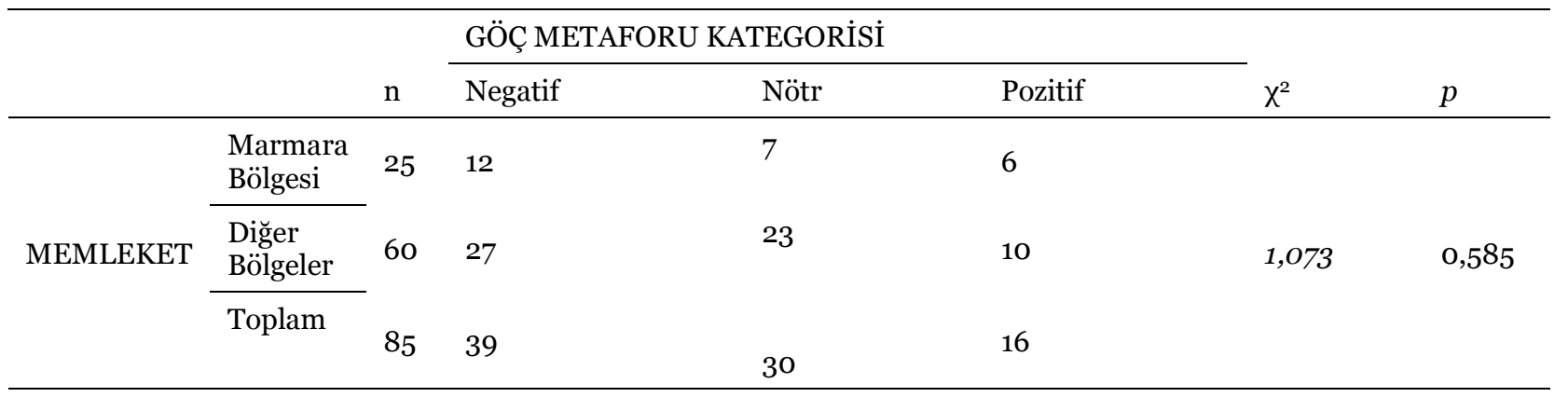

Tablo 11: Ki-Kare ilişki testi (memleket-göç metaforu kategorisi) sonuç tablosu

Ki-Kare bağımsızlık testi sonucuna göre öğrencilerin memleketi ile örnek olarak verdikleri göç metaforu kategorileri arasında istatistiksel olarak anlamlı bir ilişkiye rastlanmamıştır $\left(\chi^{2}\left({ }_{2}\right)=1,073\right.$, $p>0$,05) (Tablo 11).

\footnotetext{
\begin{tabular}{r|l} 
Adres & Address \\
İstanbul Medeniyet Üniversitesi, Eğitim Bilimleri Fakültesi, Türkçe & İstanbul Medeniyet University, Faculty of Education Sciences,
\end{tabular} ve Sosyal Bilimler Eğitimi Bölümü, Türkçe Eğitimi ABD Cevizli Turkish and Social Scinces Education, Turkish Language Teaching Kampüsü, Kartal-İstanbul/TÜRKIYE $\quad$ Education, Cevizli Campus, Kartal-İstanbul /TURKEY e-posta: editor@rumelide.com 1 e-mail: editor@rumelide.com
} 


\section{Sonuç, tartışma ve öneriler}

$\mathrm{Bu}$ araştırma, tarih bölümü öğrencilerinin göç kavramına ilişkin sahip oldukları metaforları ortaya çıkarmak, bu metaforları belli kavramsal kategoriler altında toplamak ve "Cinsiyet", "Anne Eğitim Durumu”, "Baba Eğitim Durumu” ve "Memleket (Bölge Olarak)” ile öğrencilerin örnek olarak verdikleri göç metaforu kategorileri arasında ilişki olup olmadığını tespit etmek amacıyla gerçekleştirilmiştir.

Tarih bölümü öğrencilerinin göç kavramına ilişkin olarak toplam 69 farklı metafor ürettikleri tespit edilmiştir. Öğrenciler tarafından göç kavramına ilişkin en çok tercih edilen metafor kuş $(f=8)$ olmuştur. Bu sonuç Tıkman, Yıldırım ve Şentürk (2017)'ün göç kavramına ilişkin öğrencilerin algılarını belirlemeye çalıştıkları araştırmanın sonuçlarıyla benzerlik göstermektedir. Tıkman, Yıldırım ve Şentürk (2017)'ün yaptıkları araştırmanın sonucunda da öğrenciler tarafından göç kavramına ilişkin en çok tercih edilen metafor kuş $(f=36)$ metaforu olmuştur. Canbaba (2018)'nın ortaöğretim öğrencilerinin "nüfus" ve "göç" kavramına ilişkin algılarını belirlemeye çalıştığı çalışmasında ise "göç" kavramına ilişkin olarak kuş $(f=17)$ en çok tercih edilen ikinci metafor olmuştur.

Tarih bölümü öğrencilerinin göç kavramına ilişkin geliştirdikleri metaforlar 6 kategori üzerinden değerlendirilmiştir. Katılımcıların metaforlarından hareketle oluşturulan kategoriler şunlardır: "Doğal/sıradan eylem", "çaresizlik/bilinmezlik içinde yol alış", "iyi bir hayata kavuşma arzusu", "sürekli özlem duyma", "zorunlu ayrılma/terk ediş", "yeni bir başlangıç". Öğrenciler en çok "çaresizlik/bilinmezlik içinde yol alış" kategorisinde metafor geliştirirken (21 metafor), en az "sürekli özlem duyma" kategorisinde metafor (8 metafor) geliştirmişlerdir.

Tarih bölümü öğrencileri tarafından geliştirilen metaforların \%45,9’u negatif, \%35,3’ü nötr ve \%18,8’i pozitif içerikli olduğu görülmüştür. Katılımcıların yaklaşık yarısının göç kavramına ilişkin negatif algıya sahip oldukları görülmektedir. Tıkman, Yıldırım ve Şentürk (2017)'ün göç kavramına ilişkin öğrencilerin algılarını belirlemeye çalıştıkları araştırmada da genel olarak göç kavramı öğrenciler tarafindan olumsuz metaforlarla ifade edilmiştir.

İlgili alan yazın incelendiğinde ve bu araştırmanın sonucunda elde edilen önemli bir sonuç, "göç" kavramının yalnızca tek bir metafor ile bir tam olarak açıklanabilmesinin mümkün olmadığıdır.

Bu araştırmada ayrıca IBM SPSS Statistics 20 programı ile nicel veri analizi de yapılmıştır. Sırasıyla "Cinsiyet”, “Anne Eğitim Durumu”, "Baba Eğitim Durumu” ve "Memleket (Bölge Olarak)" ile örnek olarak verilen göç metaforu kategorileri arasında bir ilişki olup olmadığına bakılmış ve bunların hiçbiri ile örnek olarak verilen göç metaforu kategorileri arasında bir ilişkiye rastlanmamıştır.

Sonuç olarak; metaforlar, tarih bölümü öğrencilerinin "göç" kavramına ilişkin algılarının neler olduğunu anlamada, ortaya çıkarmada ve açıklamada güçlü birer araştırma aracı olarak kullanabilir. Bu çalışmanın ışı̆̆ında aşağıdaki öneriler getirilebilir:

- Göç kavramına ilişkin elde edilen bulgular tarih bölümlerinde derse giren öğretim elemanlarına birbakış açısı kazandırabilir.

- Metaforlar aracılı̆̆ıyla öğrencilerin göç algısını belirlemeye yönelik farklı öğretim kademelerinde araştırmalar yapılarak sonuçlar karşılaştırılmalıdır.

\footnotetext{
Adres Address

İstanbul Medeniyet Üniversitesi, Eğitim Bilimleri Fakültesi, Türkçe İstanbul Medeniyet University, Faculty of Education Sciences, ve Sosyal Bilimler Eğitimi Bölümü, Türkce Eğitimi ABD Cevizli Turkish and Social Scinces Education, Turkish Language Teaching Kampüsü, Kartal-İstanbul/TÜRKIYE Education, Cevizli Campus, Kartal-İstanbul /TURKEY e-posta: editor@rumelide.com $\mid$ e-mail: editor@rumelide.com
} 


\section{Kaynakça}

Aydın, F. (2010). Ortaöğretim öğrencilerinin coğrafya kavramına ilişkin sahip oldukları metaforlar. Kuram ve Uygulamada Eğitim Bilimleri, 10 (3), 1293-1322.

Canbaba, Z. (2018). Ortaöğretim öğrencilerinin nüfus ve göç kavramına ilişkin algılarının metafor yöntemi ile incelenmesi. (Yayınlanmamış yüksek lisans tezi). Marmara Üniversitesi, Eğitim Bilimleri Enstitüsü, İstanbul.

Candan, A. ve Öztaş, S. (2017). Ortaöğretim öğrencilerinin tarih kavramına ilişkin sahip oldukları metaforlar. Journal of History Culture and Art Research, 6 (2), 507-526.

Cerit, Y. (2008). Öğretmen kavramı ile ilgili metaforlara ilişkin öğrenci, öğretmen ve yöneticilerin görüşleri. Türk Eğitim Bilimleri Dergisi, 6 (4), 693-712.

Göç Terimleri Sözlüğü. (2013). Uluslararası Göç Örgütü (IOM) https://publications.iom.int/system/files/pdf/iml31_turkish_2ndedition.pdf (Erişim Tarihi: 14.12.2019).

Gürkan, B. (2017). Öğrencilerin "Göç" ve "Mülteci" Kavramlarına İlişkin Algıları: Bir Metaforik Analiz. O. Köse (Ed.), Geçmişten Günümüze Göç III içinde (s. 1817-1830). Samsun: Canik Belediyesi Kültür.

Kılınç, F. E., Karayel, F. ve Koyuncu, M. (2018). Türk ve Suriyeli çocukların göç kavramına ilişkin metaforlarının belirlenmesi. Sosyal Politika Çalş̧maları Dergisi, 40 (2), 37-54.

Lakoff, G., \& Johnson, M. (1980). Metaphors we live by. Chicago and London: University of Chicago Press.

Marshall, G. (1999). Sosyoloji sözlüğü, Çev: Osman Akınhay ve Derya Kömürcü, Ankara: Bilim ve Sanat.

Miles, M. B., \& Huberman, A. M. (1994). Qualitative data analysis: An expanded sourcebook. Thousand Oaks, CA: Sage Publications.

Saban, A. (2004). Giriş düzeyindeki sınıf öğretmeni adaylarının "öğretmen” kavramına ilişkin ileri sürdükleri metaforlar. Türk Eğitim Bilimleri Dergisi, 2, (2), 131-155.

Saban, A. (2009). Öğretmen adaylarının öğrenci kavramına ilişkin sahip oldukları zihinsel imgeler. Türk Ĕ̆itim Bilimleri Dergisi, 7 (2), 281-326.

Usta, Ç. (2016). Göç ve metafor. A. Köksal (Ed.)., Zamanın izleri: İşgal, göç ve muhacirlik içinde (s.161-172). Trabzon: Karadeniz Teknik Üniversitesi.

Tıkman, F., Ylldırım, E. ve Şentürk, M. (2017). Göç metaforuna yolculuk: Bir fonomenolojik çalışma. Sosyal Bilimler Dergisi, 7 (14), 104-126.

Türk Dil Kurumu (TDK). (1988). Türkçe sözlük. Ankara: Türk Dil Kurumu.

Türkiye Bilimler Akademisi (TÜBA). (2011). Türkçe bilim terimleri sözlüğü sosyal bilimler. Ankara: TÜBA.

Yıldırım, A. ve Şimşek, H. (2008). Sosyal bilimlerde nitel araştırma yöntemleri. Ankara: Seçkin.

\footnotetext{
Adres $\mid$ Address

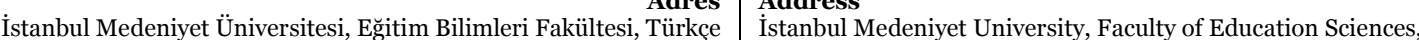
ve Sosyal Bilimler Eğitimi Bölümü, Türkçe Eğitimi ABD Cevizli Turkish and Social Scinces Education, Turkish Language Teaching Kampüsü, Kartal-İstanbul/TÜRKIYE Education, Cevizli Campus, Kartal-İstanbul /TURKEY e-posta: editor@rumelide.com $\mid$ e-mail: editor@rumelide.com
} 